P-ISSN : 1412-6141

E-ISSN : $2548-7744$

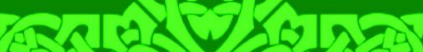
is 120 2ह

51030.

Muhammad Syahran

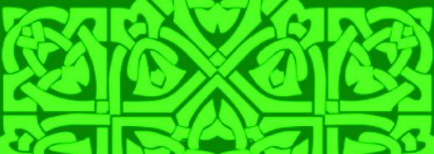
I of Humanities and Islamic Studies

(1) Al-Islām min Al-Ta'àlīm Ilā Al-Taṭbīqāt, Musykilat Al-Jisr Al-
Maqț'

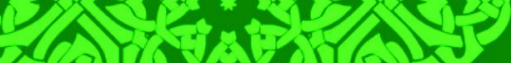

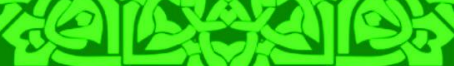

रति 03

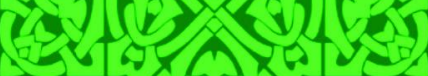

पer

(1)

Salafi and Social Religion Dynamics In Kendari

Muhammad Tahir Alibe, Abdul Muiz Amir

The Infallibility of The Prophet Muhammad Pbuh. As A Human Being (A Study Of His Ijtihad)

Muhammad Saleh Tajuddin The Role of Abdurrahman Wahid in Creating Islamic PostTraditionalist Paradigm in Indonesia

Muh Ilham Usman

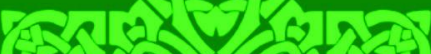

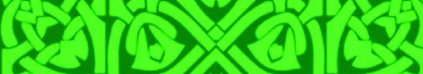
520

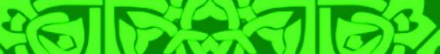
ff 20 is
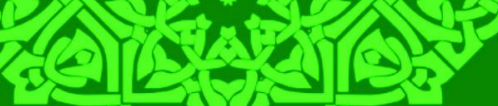

Cर ति 25 (a)

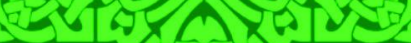
L in $\rightarrow$ Th

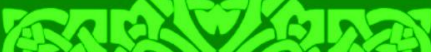
IC म 121 $1<$ 20

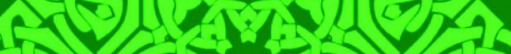

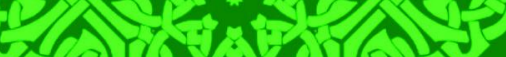

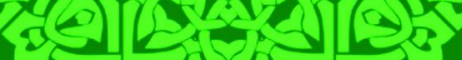

Tasmin Tangngareng, Hasbullah A Prophetic Study On Earthquake

Usman Jafar

Muslims' Thoughts of Non-Muslims' Political Rights in Majority Muslim Areas in Makassar 


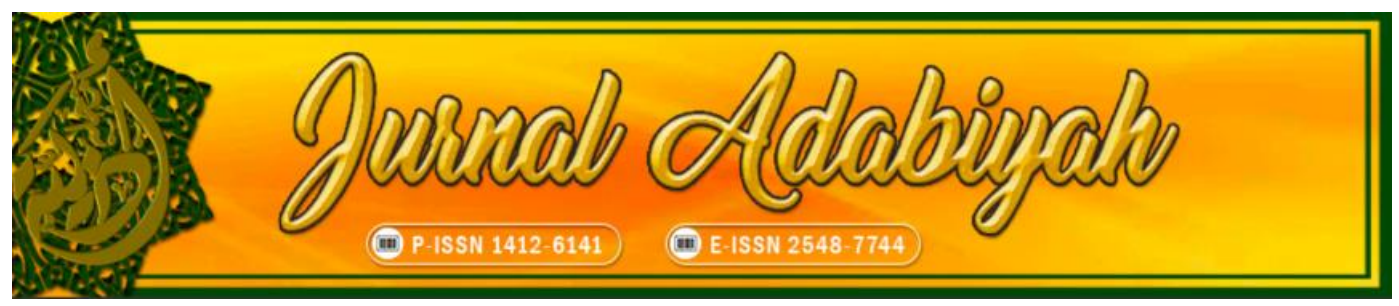

Thema: Islamic Studies

VOLUME 19 NO. 2 DESEMBER 2019

EDITOR-IN-CHIEF

Barsihannor, Alauddin State Islamic University, Indonesia

INTERNATIONAL EDITORIAL BOARD

Nuri Emmiyati, Alauddin State Islamic University, Indonesia

Minako Sakai, Australian National University (ANU), Australia

Abd Rauf Muhammad Amin, Fakulti Syariah Kupu SB Brunei Darussalam, Brunei Darussalam

Muhammad Zakir Husain, Universiti Islam Sultan Sharif Ali, Brunei Darussalam

Muhammad Widus Sempo, Universiti Sains Islam Malaysia, Malaysia

Salih Yousif Sharaf Mohamed, Al-Gazera University, Sudan

Aishah Waenaha Waemamah, Academy of Islamic and Arabic Studies Princess of Naradhiwas University - Thailand, Thailand

EXECUTIVE EDITOR

Umar Thamrin, Universitas Islam Negeri Alauddin, Indonesia

MANAGING EDITOR

Zaenal Abidin, Universitas Islam Negeri Alauddin

\section{EDITORS}

Rosmah Tami, Alauddin State Islamic University, Indonesia

Haniah, Alauddin State Islamic University, Indonesia

Nasrum, Alauddin State Islamic University, Indonesia

Awaluddin Syamsu, Universitas Muslim Indonesia

Ahmadi Usman, UIN Syarif Hidayatullah Jakarta, Indonesia

Baso Pallawagau, Alauddin State Islamic University, Indonesia Muhammad Azwar, Universitas Islam Negeri Syarif Hidayatullah Jakarta, Indonesia

Muh. Saleh Syamsuri, Alauddin State Islamic University, Indonesia

Andi Satrianingsih, Muhammadiyah University, Indonesia

Syahruni Junaid, Alauddin State Islamic University, Indonesia

Rabiatul Adawiah, Majene Islamic State College, West Sulawesi, Indonesia, Indonesia

Chusnul Chatimah Asmad, Alauddin State Islamic University, Indonesia

Nur Arifin, Alauddin State Islamic University, Indonesia

\section{IT SUPPORT}

Taufiq Mathar, Alauddin State Islamic University, Indonesia

\section{LANGUAGE ADVISOR}

Kustiwan Syarief, UIN Syarif Hidayatullah Jakarta, Indonesia

Muh. Saleh Syamsuri, Alauddin State Islamic University, Indonesia

\section{COVER DESIGNER}

Nur Arifin 


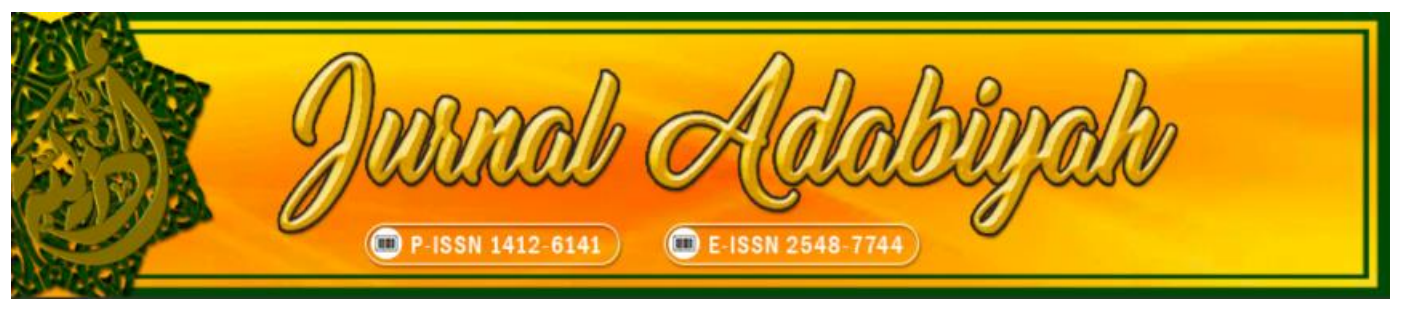

\section{Jurnal Adabiyah:}

This journal receives a national accreditation from Ministry of Research, Technology, and Higher Education Republic of Indonesia, Nomor 10/E/KPT/2019 on April 4, 2019 with the SINTA score: S2.

The Journal has been published by the Faculty of Adab and Humanity of Alauddin State Islamic University, Makassar, since 1997 and has been online since 2016 with the main themes on Humanities and Islamic Studies with the emphasis on interdisciplinary and intertextuality approach.

This journal are published twice a year, on June and December. The themes related to Islamic Studies are textual studies, scriptural traditions, Islamic law, and theology; and those related to Humanities are language, literature, history, and culture.

The journal of Humanities and Islamic Studies will provide the online collection of articles from 1997 up to now. The most updated information can be found on the website. 


\section{Table of Contents}

Muhammad Syahran

103-121

Al-Islām min Al-Ta'ālìm Ilā Al-Tațbīqāt, Musykilat Al-Jisr Al-Maqț'

Abbas

$122-136$

Salafi and Social Religion Dynamics in Kendari

Muhammad Tahir Alibe, Abdul Muiz Amir

137-156

The Infallibility of The Prophet Muhammad Pbuh. As A Human Being

(A Study Of His Ijtihad)

Muhammad Saleh Tajuddin

157-171

The Role of Abdurrahman Wahid in Creating Islamic Post-Traditionalist Paradigm in Indonesia

Muh Ilham Usman

172-185

Islam and Agrarian: Study of Nahdhatul Ulama's Religious Social Thought

Tasmin Tangngareng, Hasbullah

186-203

A Prophetic Study on Earthquake

Usman Jafar.

204-223

Muslims' Thoughts of Non-Muslims' Political Rights in Majority Muslim Areas in Makassar 


\title{
THE INFALLIBILITY OF THE PROPHET MUHAMMAD PBUH. AS A HUMAN BEING (A STUDY OF HIS IJTIHAD)
}

\author{
Muhammad Tahir Alibe, ${ }^{1} \&$ Abdul Muiz Amir. ${ }^{2}$ \\ ${ }^{1}$ Fakultas Ushuluddin, Institut Agama Islam Negeri (IAIN) Manado \\ Email: muhammad.tahir@iain-manado.ac.id \\ ${ }^{2}$ Fakultas Ushuluddin Adab dan Dakwah, Institut Agama Islam Negeri (IAIN) \\ Kendari \\ Email: abdulmuiz@iainkendari.ac.id
}

\begin{abstract}
This study aims at examining the concept of the infallibility of the Prophet Muhammad as a human being in general based on the context of the interpretation of the Qur'an. This study will answer the question of why the Prophet Muhammad considered infallible, even though he had made a mistake in conducting ijtihad?. This study used qualitative methods based on the critical theory paradigm and theory of semantic analysis and historical contextual. The results showed that the Prophet Muhammad considered an infallible man based on the context of the use of "basyar" term in the Qur'an. The term "basyar" is always attached to the Prophet as the recipient of revelation, so it shows that Muhammad was an infallible human being. If the Prophet makes a mistake, he will always get a reprimand from Allah. This privilege is indeed not owned by other humans. This research ultimately refutes the argument that the Prophet's mistake in carrying out "ijtihad" shows his ineptitude as an ordinary person.
\end{abstract}

Keywords: The Ijtihad; The Infallible; Muhammad as a Human Being;

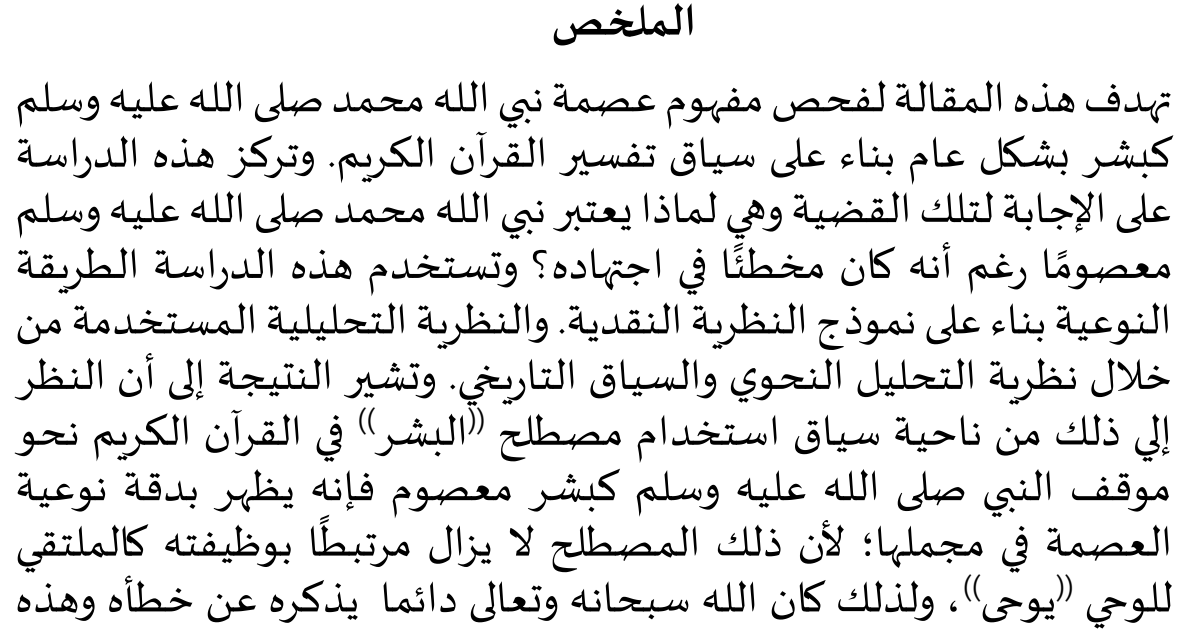




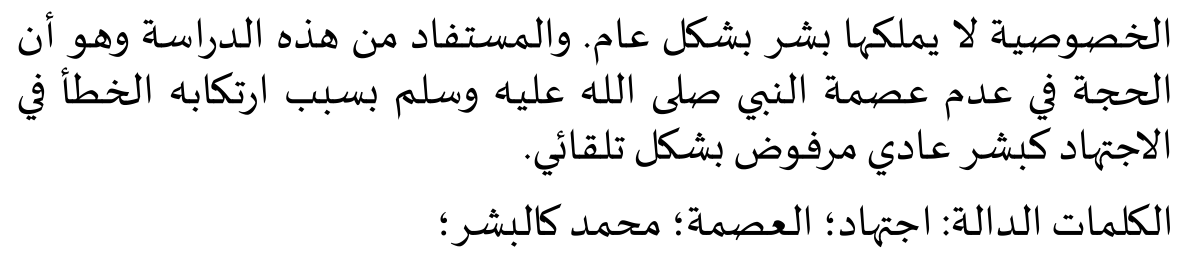

\begin{abstract}
Abstrak
Artikel ini bertujuan untuk membedah konsep kemaksuman Nabi Muhammad sebagai manusia pada umumnya berdasarkan konteks penafsiran Al-Qur'an. Kajian ini fokus untuk menjawab pertanyaan permasalahan terkait, mengapa Nabi Muhammad dianggap maksum, padahal ia pernah melakukan kekeliruan dalam berijtihad?. Kajian ini menggunakan metode kualitatif berdasarkan paradigma teori kritis. Sedangkan teori analisis yang digunakan melalui tinjauan analisis gramatikal bahasa dan kontekstual historis. Hasil temuan menunjukkan bahwa, bila ditinjau berdasarkan konteks penggunaan term basyar di dalam Al-Qur'an terhadap posisi Nabi Muhammad sebagai manusia yang maksum, maka justru hal tersebut menunjukkan kualitas kemaksumannya secara totalitas, sebab term tersebut selalu melekat pada fungsinya sebagai penerima wahyu (yuha), sehingga kekeliruannya senantiasa mendapatkan teguran dari Allah. Keistimewaan tersebutlah yang tidak dimiliki oleh manusia pada umumnya. Adapun implikasi dari kajian ini secara otomatis membantah argumen yang menyatakan bahwa kekeliruan ijtihad yang pernah dilakukan oleh Nabi Muhammad menunjukkan ketidak maksumannya sebagai manusia biasa.
\end{abstract}

Kata Kunci: Ijtihad; Kemaksuman; Muhammad sebagai manusia;

\title{
A. Introduction
}

Based on the theological dogma that is believed by Muslims, that essentially the Prophets are guarded against sin and mistake which is contrary to the concept of the religion they teach. ${ }^{1}$ These conditions are termed by scholars as infallible ${ }^{2}$ pinned

\footnotetext{
${ }^{1}$ Muslim b. al-Hajjāj Abū al-Ḥasan al-Qusyāyrī al-Naysābūrī, Al-Musnad al-Ṣahīh alMukhtașar bi al-Naqlī al-'Adl 'an Rasulillāh saw. (Beirut: Dār Ihyā' al-Turāì al-'Arabī, n.d.), h. 1836.

${ }^{2}$ According to Ibn Hazm infallibility ('ișma) is the preservation of the Prophet Muhammad from mistakes, small and large sins. Some scholars say that the Prophet Muhammad was infallible when he received revelations and delivered revelations, but on the other hand he also admitted that the Prophet Muhammad could make mistakes because when he made an ijtihad, when he made it could fall into error by quoting some of the history that Prophet Muhammad once fell into error. Look in Sulaiman b. Ahmad
} 
to the Prophets, especially the Prophet Muhammad. These characteristics also became a substantial differentiator between the Prophets and ordinary people. ${ }^{3}$ However, if viewed historically, it is found several events from the behavior of the Prophet who received a rebuke from Allah through revelation. ${ }^{4}$ This shows that despite the Prophet Muhammad is the Messenger of Allah who gained the legitimacy of infallibility, on the other hand, the Prophet Muhammad had the opportunity to make mistakes like ordinary people, as revealed in QS. Al-Kahfi//18: 110 which mentions the following:

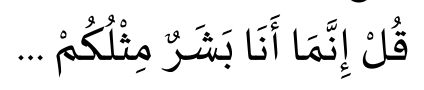

The translation:

Muhammad says; that I am a human like you all,...

Al-T abari explained that the verse aims to answer the questions of the Quraish infidels regarding the position of the Prophet as an ordinary person who knows nothing except what Allah teaches through revelation. ${ }^{5}$ This means that the Prophet Muhammad in his behavior was not always in the position of the infallible Prophet, but also sometimes in the position of an ordinary human being who had the opport unity to make mistakes. One of the narrations of the Hadith that explains that the Prophet Muhammad was considered to have made a mistake can be seen in the history of the following Hadith:

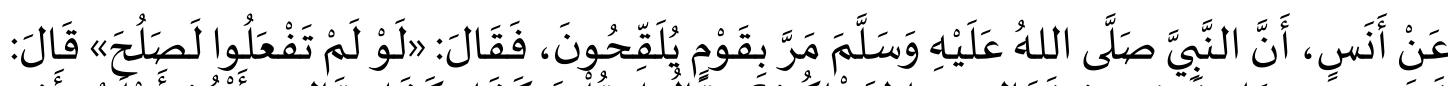

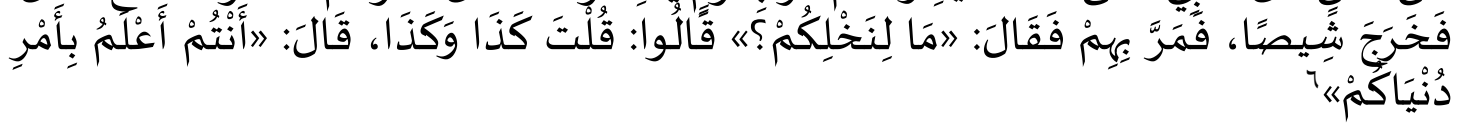

The meaning:

(From Anas that the Prophet (PBUH) once passed by a group of people who were marrying palm trees, then he said: "If they did not, the dates would (remain) good." But after that, it turned out that the dates grew damaged. Until one day the Prophet (PBUH) passed by them again and saw that he asked:

b. Ayyub Abu al-Qāsim al-Ṭabrānī, Al-Mu'jam al-Kabīr (Cairo: Maktabah Ibnu Taimiyyah, 1415), h. 47.

${ }^{3}$ Syahrin Harahap and Hasan Bakti Nasution, Ensiklopedia Akidah Islam (Jakarta: Kencana, 2009), h. 277.

${ }^{4}$ There are several verses of the Qur'an which indicate the descent of the verse as a form of Allah's rebuke of the acts of neglect of the Prophet Muhammad as ordinary human beings, among which can be seen in QS. 'Abasa/80:1-4, QS. Ali 'Imrān/3:128, QS. Al-Tahrīm/66:1, QS. Al-Taubah/9:43 and 84, and QS. Al-Anfāl/8:67.

${ }^{5}$ Muḥammad bin Jarīr al-Ṭabarī, Jāmī‘ al-Bayān fì Ta'wīl Al-Qur'ān, Cet. I. (Beirut: Mu'assasah al-Risalāh, 2000), h. 135. 
What's going on with your palm tree? They answered; Didn't you say this and that? He then said: 'You know your world affairs more)

The consequences of the history of the Hadith above shows that the Prophet Muhammad (PBUH), was wrong in giving instructions to his people that was not on his capacity as a Prophet. In addition, the history also emphasizes that the understanding of secularists that separates world and hereafter affairs may be true, meaning that when the Prophet is confronted with worldly affairs, the Prophet Muhammad could be wrong. But on the other hand, this history is not in harmony with the spirit of the Qur'an which confirms that the Prophet Muhammad could not speak without the basis of knowledge or lust, as mentioned in QS. al-Najm/53: 3-4. The verse explains about the talk of the Prophet based on the guidance of revelation.

Besides the history above, the author also found a number of histories which were considered by ulama or scholars as valid Hadiths when viewed in terms of sanad, but was doubtful when viewed from the term of view. One example is the history which mentions when the Prophet Muhammad forgot to take a junub bath when he fasted in Ramadan, which he later remembered when he was about to lead the morning prayer. ${ }^{7}$ History like this can invalidate the infallibility of the Prophet Muhammad when it is associated with the definition of the infallibility of the Prophet which the author explained earlier.

The problem is that if the Prophet Muhammad was regarded as infallible in the sense of being free from total errors, then is it possible that he gave instructions without knowledge? Therefore this study will talk about the concept of infallibility of the Prophet Muhammad in the Qur'an which will reveal the quality of the infallibility of the Prophet Muhammad by examining the three terms used by the Qur'an and Hadith when talking about humans namely, term basyar, insan, al-nas. So the formulation of the problem in this study is why the Prophet Muhammad was considered infallible, even though he had made a mistake in conducting ijtihad?

Previous studies about the concept of the Prophet's infallibility have been carried out by several researchers, including Fuadi (2018) who revealed that the views of the commentators about the infallibility of the Prophet in totality, both from the dangers posed externally (disturbances of supernatural beings) and internal (human error). The guardianship was guarded by Allah through revelation which was a direct rebuke to correct the mistake. ${ }^{8}$ Sriwahyuni (2017) revealed that the mistakes made by the Prophet were Allah's way of perfecting the humanity of the Prophet, wherein the follows:

${ }^{7}$ The events of the Prophet forget about the junub bath enshrined in the history of the hadith as

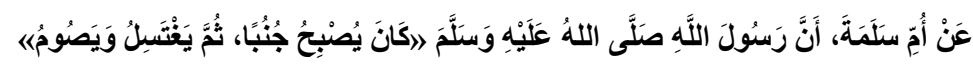

Look in Abū Daud Sulaiman b. al-Asy’as al-Sijistān̄i, Sunan Abī Daud, Cet. I. (Beirut: Dār al-Kutub Risālah al-'Ilmiyah, 2009). Juz 3, h. 179.

${ }^{8}$ Alfin Rahmat Fuadi, "Pandangan Mufasir Tentang Sifat Kemaksuman Nabi Muhammad Saw" Skripsi Fakultas Ushuluddin dan Filsafat, (Aceh: Universitas Islam Negeri Ar-Raniry, 2018), h. 1-106. 
Prophets' infallibility lays. ${ }^{9}$ Tajuddin (2018) revealed about the comparative side between the views of Al-Tabarsi and Al-Qurtubi regarding the infallibility of the Prophets Ulul 'Azmĩ in their commentary, Tajuddin concluded that Al-Tabarsi did not consider the Prophet's infallibility to be wrong, while Al-Qurt ubi seeing this error was still considered an error even though it did not harm the infallibility of the Prophets. ${ }^{10}$ Rizvi (2014) considers that the prophecy of the Prophets is only used to find out the negative side, whereas when examined more deeply through a comparative study between Sunni and Shi'a ideologies, it is found that the concept of infallibility which is basically the behavior of the Prophets reveals positive messages that are more dominant on the dominant the benefit side of humanity. ${ }^{11}$ Ferrero (2011) through his article criticizes the dogma of infallibility towards the papacy by Catholics. Ferrero dealt with many irregularities and manipulation of immorality constructed by the Roman Catholic church in 1870 in order to preserve their rule. ${ }^{12}$ Ahmad (2011) in his study analyzed the transformation of Imām Hanāfî's thoughts related to the concept of the infallibility of the Prophet Muhammad. Āanāfi considers that the Prophet's immorality was only in the process of receiving and delivering the revelations, while other behaviors made it possible for the Prophet to make small or large mistakes. Ahmad through his studies using the QS foundation. 8: 67 concluded that in its development the Hanāfi thought then changed and assumed that the mistakes made by the Prophet were only on minor matters that were not directly related to revelation. ${ }^{13}$

The study of previous research was certainly different from this study, because if the previous study only focused on the infallible epistemology ('isma) according to the scholars' interpretation only, so this study would classify and map the infallibility of the Prophet Muhammad and his position as a messenger of Allah (Rasulullah). Therefore, to answer the problem focus of this study, the author uses a type of qualit ative method based on the theoretical critical theory paradigm of the infallibility of the Prophet Muhammad. The data used in this study is literature data (literature review) using verses from the interpretation of the Qur' an and the hadith as primary data sources, while other similar sources of literature are used as secondary data sources. The data collected is then analyzed using interpretative intra-text and intertext theory which makes the writer the subject of pure interpreters.

\footnotetext{
${ }^{9}$ Sriwahyuni. Sriwahyuni, "Kemaksuman Nabi: Kajian Terhadap Ayat-Ayat 'Ita $>$ b Terhadap Nabi Muhammad Saw.," Jurnal At-Tibyan: Jurnal Ilmu Alquran dan Tafsir 2, no. 2 (2017): 189-206.

${ }^{10}$ Muhammad Tajuddin, “Kontroversi Kemaksuman Rasul Ulul ‘Azmi Dalam Al-Qur’an (Studi Komparatif Tafsir Al-Thabarsi Dan Al-Qurthubi)” Tesis Prodi. Studi Ilmu Agama Islam, (Malang: Universitas Islam Negeri Maulana Malik Ibrahim, 2018).

${ }^{11}$ Sayyid Muhammad Rizvi, The Infallibility of the Prophets in the Qu'ran (Cambridge: CreateSpace Independent Publishing Platform, 2014), 1-38.

${ }^{12}$ Mario Ferrero, "The Infallibility of The Pope," Economics of Governance Vol. 12, no. 1 (2011): 89-99.

${ }^{13}$ Rumee Ahmed, "The Ethics of Prophetic Disobedience: Qur'an 8: 67 at The Crossroads of Islamic Sciences,” Journal of Religious Ethics Vol. 39, no. 3 (2011): 440-457.
} 


\section{B. The Epistemology of 'Ismah in The Qur'an}

In the language of the word infallible comes from Arabic, namely 'asama ${ }^{14}$ which is taken from the word 'asama-ya'sim-'asman which means preventing, obstructing, guarding, and maintaining. ${ }^{15}$ Whereas according to the term infallible is the guardianship of the prophets from all forms of disgraceful deeds. ${ }^{16}$ The basic epistemology of the term 'isma or infallible is based on the study of the Qur' an and Hadith. Therefore the study of the concept of infallibility is not without foundation but has a strong footing, both from the text of the Qur' an and Hadith using the term 'isma.

According to Subhani the word 'isma in the Qur' an is mentioned thirteen times with various kinds of derivations, ${ }^{17}$ but all of them contain one understanding. While by Ibnu Faris it is revealed that the word isma comes from one root word which refers to imsak (refrain) mana'a (prevent), and mulazimah (determination or alive), thus it can be concluded that the meaning of 'isma is converging on one meaning of the basic meaning that is prevented or protected. ${ }^{18}$

When exploring further about the use of the word 'isma in the Qur'an, it is found that the word is also used in QS. Ali ' $I m r a \bar{n} / 3$ : 103 as follows:

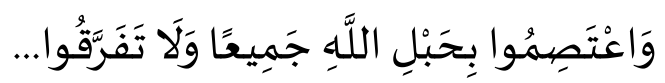

The translation:

You hold fast to Allah's rope and do not separate...

The word "wa 'tasimul in this verse is one form of the derivation of the word "isma which means "hold fast". This is because the Arabs in the early Islamic period also used the word 'isma as a term for the rope used to tie their herding animals so they would not easily divorce/separate. ${ }^{19}$ In the dictionary, Al-Mufid mentions that isma in the original language is something held by humans with whom it is preserved and protected from what is not desired..$^{20}$

${ }^{14}$ Ahmad Warson Munawwir, Kamus Al-Munawwir (Surabaya: Pustaka Progressif, 1997), 939.

${ }^{15}$ Ibnu Manẓūr, Lisān al- 'Arab (Beirut: Dār Șādir, 1410). Jilid 12, h. 403-404.

${ }^{16}$ Ahsin Wijaya, Kamus Ilmu Al-Qur'an (Jakarta: Amzah, 2012), h. 123.

${ }^{17}$ Look in, QS Hūd/11: 43, QS Al-Mā'idah/5: 67, QS Al-Ahzāb/33:17, QS Al-Nisā'/4: 146, dan 175, QS Āli 'Imrān/3: 10, dan 103, QS Al-Hājj/22: 78, QS Yūsuf/12: 32, QS Yūnus/10: 27, QS AlMu'min/40: 33, QS Hūd/11: 43, dan QS Al-Mumtahanah/60: 10. Look in Syaikh Hasanain Muhammad Makhluf, Al-Mu'jam Al-Mufahras li Kalimāt Al-Qur'ān al-Karīm, Tafsīr wa Bayān Kalimāt Al-Qur'ān al-Karīm, Cet. I. (Beirut: Dār Ibn Kas̀īr, 2005), h. 219.

${ }^{18}$ Syeikh Ja'far Subhānī, Mafāhim Al-Qur'ān (Beirut: Mu'assasah al-Tarīkh al-'Arabī, 2010)., Juz 5, h. 231.

${ }^{19}$ Syeikh Ja'far Subhān̄̄, Mafāhim Al-Qur'ān, h. 8-9.

${ }^{20}$ Syeikh Ja'far Subhānī, Mafāhim Al-Qur'ān, h. 9. 
According to Subhani who defines the word 'isma as a form of guidance from Allah which is obtained through obedience, so that it can save people from all forms of ugliness. Something similar can be exemplified as someone who is holding out a rope to help a person who is drowning so that he clings to the rope, making him safe. But if the rope is ignored or the drowning person does not cling to it, then he cannot call it "isma." ${ }^{21}$ Therefore, Subhani concluded that what is meant by ismah is human maintenance from mistakes and sins, even he is preserved from his thoughts and desires. This means that people are infallible, so he absolutely will not do wrong and sinners to God during his life. ${ }^{22}$ This infallibility is one of the characteristics and peculiarities of the Prophets. This infallible character is the virtue of the Prophet thanks to his virtues, faith, knowledge, and piety which have reached the pinnacle of perfection and glory of existence as humans, then they consciously distance themselves from all deeds, even beyond the reach of their thoughts. ${ }^{23}$

\section{Concepts of Basyar, Insān, and Nās Perspective of the Qur'an}

Shihab argues that there are three types of words used by the Qur'an to refer to human terms, namely; (1) Using basyar words consisting of the composition of the letters alif, nun, and sin which includes insān, ins, nas or unas, (2) Using the word basyar, and (3) Using the words bani adam, and zurriyah adam. The word basyar is taken from the root of the word which at first means "the appearance of a good and beautiful one". From the root of the same word is the word basyarah which means skin. Therefore humans are called basyar because their skin is clear, and different from other animal skins. ${ }^{24}$ When examined in the Qur'an, it is found that the word basyar mentioned 36 times in the singular (mufrad) and once in the form of two (mutsanna). The use is to designate people from the outward side and their similarities with humans in general. Therefore, the Prophet Muhammad (PBUH) was ordered to say that "I am a basyar like you who were given revelation"25

From the other side, it was observed that the verses of the Qur'an which use the word basyar indicate that the process of human events in basyariyah, through several stages to reach the stage of maturity. This can be seen in the Qur'an which says "And among the signs of His power you created you from the ground, then when you became a basyar/preacher you scattered. ${ }^{26}$ The word "scattered" in the verse can be interpreted as breeding through relationships sex, can also be understood by

${ }^{21}$ Syeikh Ja'far Subhān̄̄, Mafāhim Al-Qur'ān, 9-10.

${ }^{22}$ Syeikh Ja'far Subhānī, Mafāhim Al-Qur'ān, 10.

${ }^{23}$ Muhsin Qira'ati, Ushuluddin (Lesson from Al-Qur'an), ed. M.J Bafaqih and Dede Azwar Nurmansyah (Jakarta: Cahaya, 2007), h. 257.

${ }^{24}$ Muhammad Quraish Shihab, Wawasan Al-Qur'an: Tafsir Maudhu'i Atas Perbagai Persoalan Umat, Cet. XIII. (Bandung: Mizan, 2003), 278-279.

${ }^{25}$ Look in QS. Al-Kahfĩ/18: 110.

${ }^{26}$ Look in QS. Al-Rūm/30: 20. 
scattering in search of life. These two things are not done by humans except those who have maturity and responsibility. Likewise, the word "basyarahunna" used in the Qur'an twice shows the meaning of intercourse. ${ }^{27}$ Therefore, the task of the caliphate is imposed on the basyar, notice the expression of Allah in QS. Al-Hijr/15: 28 which uses the word basyar and QS. Al-Baqarah/2: 30 which uses the word khalifah, both of which contain meaning related to Allah's information to Angels about humans. ${ }^{28}$

The word "insan" is taken from the root word "uns" which means tame, harmonious, and impact. But if viewed from the point of view of the meaning of the Qur'anic context, it is more appropriate if the word "uns" is taken from the word "nasiya" (forget), or nasa-yanusu (shaking). The Holy Qur' an often elaborates on the word man with jin or jan. Jin is an invisible supernat ural being, while humans are real, friendly beings. Insan said the Qur' an is used to designate people with all their totality, body, and soul. The use of the word wants to at the same time want to show that humans are different from other creatures, these differences include the physical, mental, and intelligence forms they have. ${ }^{29}$

When examined about the process of creation of man created from the ground and after perfect, the event is blown into him the God's Spirit. ${ }^{30}$ From this it is clear that human beings are the unity of two basic elements, which cannot be separated if they are separated, then they are no longer worthy of being called human As with water which is a combination of oxygen and hydrogen in certain levels if the oxygen and hydrogen levels are separated, it is not worth mentioning as water. ${ }^{31}$

The word basyar shows humans biologically, outwardly. So, in the basyariyya the Prophet was the same as humans in general who needed food and drink. However, in terms of humanity, the Prophet was a perfect human, as the poem expresses that the Messenger of Allah, basyarun la-ka'l-basyar (the Messenger of Allah as a human being, but unlike ordinary humans). The humanitarian side of the Prophet with humans, in general, is like diamonds in the midst of ordinary stones. Diamond is one type of stone but the diamond has a price that is more valuable than rocks in general. ${ }^{32}$ Same as the Prophet as a human figure that is different from humans in general.

The word "unas" is called five times in the Qur' an. ${ }^{33}$ which shows the meaning of groups or groups of people. For example in QS. Al-Baqarah/2: 60, the word unas is used to indicate 12 groups in the children of Israel. The word "anasis" is only called once, namely in QS Al-Furqān/25:49, the word anasis is the plural form of the insan word, by replacing the letters nun and ya, or is the plural form of the word "insi", like

${ }^{27}$ Look in QS Al-Baqarah/2: 187.

${ }^{28}$ Shihab, Wawasan Al-Qur'an: Tafsir Maudhu'i Atas Perbagai Persoalan Umat., h. 279-280.

${ }^{29}$ Ibid.

${ }^{30}$ Look in QS. S̄ād/38: 7.

${ }^{31}$ Shihab, Wawasan Al-Qur'an: Tafsir Maudhu'i Atas Perbagai Persoalan Umat, h. 282.

${ }^{32}$ Jalaluddin Rakhmat, Soal-Soal Islam Kontemporer, Cet. I. (Bandung: Mizan, 1998)., h. 288.

${ }^{33}$ Look in Lihat QS. Al-Baqarah/2:60; QS. Al-A'rāf/7:82; QS. Al-Ma'ārij/70:160; QS. AlIsrā'/17:17; Al-Naml/27:56. 
a chair, become karasi. The word Ins is called 18 times in the Qur'an, and is always associated with the genie as a partner for human beings who are capable of forgiving. ${ }^{34}$

The word "basyar", referred to 27 times with all its derivatives. All verses that mention the word basyar indicate the meaning of humans as biological beings. One of them can be seen when Mary said to her Lord, "my god, how could I have a child, even though I was not touched by a basyar". ${ }^{35}$ The word basyar is associated with mitslukum as many as seven kalidan misluna six times in the Qur'an. It means that the Prophet Muhammadiyah was ordered by Allah to assert that biologically, he is like a human in general, as the word of Allah in the Qur' an "say, I am an ordinary man (basyar) like you, only I am given a revelation that your God is God one". ${ }^{36}$ Likewise, the expression of the infidels mentioned in the Qur'an 'is it not like you, he eats what you eat, and he drinks what you drink." 37 The other verse also mentions the same thing, as in QS. Al-Furqān / 25: 7, "does the Apostle eat food, and walk in the market". Likewise, the verse that alludes to Egyptian women who were astonished at seeing Joseph's good looks while saying, "Oh God, this is not basyar, but this is nothing but a noble angel". ${ }^{38} \quad$ Briefly, the concept of basyar is always associated with human biological characteristics: eating, drinking, and having sex. Therefore the word "basyarun mislukum" cannot be interpreted as a human in general in terms of the opport unity to sin, because the tendency of the Prophets not to fall prey to the puddles of sin and error is not from the part of biological traits, but it is psychological traits or spiritual. It is equally incorrect to interpret the verse of the Qur'an "in fact we have made human beings in the best form", ${ }^{39}$ by showing the characteristics of human physicology. ${ }^{40}$

The word "insān" is mentioned 65 times in the Qur'an with all its derivatives. Rakhmat in Islam and Pluralism groups human context into three categories. First, human beings are associated with their privileges as caliphs or trustees; Secondly, human beings are associated with negative predictions from humans, and third, human beings are associated with the process of human creation. All human contexts refer to psychological or spiritual traits. ${ }^{41}$

${ }^{34}$ Look in QS. Al-An'ām/6:112, 128, 130; QS. Al-A'rāf/7:38, 179; QS. Al-Isrā'/17:88; QS. AlNaml/27:17; QS. Fușṣilāt/41:25, 29; QS. al-Aḥqāf/46:18; QS. Al-Zāriyāt:51:56; QS. Al-Rahmān/55:33, 39, 56, 74; QS. Al-Jīn/72: 5, 6.

${ }^{35}$ Look in QS. Āli ‘Imrān/3:47.

${ }^{36}$ Look in QS Al-Kahfĩ/18: 110; and QS. Fușșilāt/41: 6.

${ }^{37}$ Look in QS. Al-Aḥzāb/33:33.

${ }^{38}$ Look in QS. Yūsuf/12: 31.

${ }^{39}$ Look in QS. Al-Tīn/95: 4.

${ }^{40}$ Jalaluddin Rakhmat, Islam Dan Pluralisme Akhlak Quran Menyikapi Perbedaan, Cet. II. (Jakarta: Serambi Ilmu Semesta, 2006), h. 124-126.

${ }^{41}$ Jalaluddin Rakhmat, Islam Dan Pluralisme Akhlak Quran Menyikapi Perbedaan, h. 127. 
In the first category, we can see the special features of humans as different forms of animals, as mentioned in the Qur'an that humans are beings who are given knowledge, "who teach with pens, teach what people do not know"42 Allah teaches human beings everything they do not know " allamahu al-bayān". ${ }^{43}$ Humans are given the ability to develop knowledge and reasoning power. Therefore, in the Qur'an it is always mentioned that human words are side by side with the word nazhar (study), meaning that the word human is always oriented to reflecting, thinking, analyzing, and assessing his actions. ${ }^{44}$ The nazhar in question can be in the form of an analysis of the process of forming food from the pouring of rainwater to the formation of fruit ${ }^{45}$ and its creation. ${ }^{46}$

Second, humans are creatures who carry trust. ${ }^{47}$ Rahman revealed that the mandate is to find the law of nature, master it, or in the Al-Qur'an to use the term, "know the names of all" and then use them, with human moral initiatives, to create a better world order. Third, because humans carry the mandate, the person in the Qur'an is also connected with the concept of responsibility, ${ }^{48}$ his charity is carefully recorded to be rewarded according to what he does. ${ }^{49}$ Therefore, it is humans who are hostile to Satan $^{50}$ and are determined by their fate on the Day of Judgment. ${ }^{51}$ Fourth, in worshiping God, human beings are very much connected with negative predispositions in humans. According to the Qur'an, humans tend to be unjust and disbelievers, ${ }^{52}$ hurry, ${ }^{53}$ naughty ${ }^{54}$ ignorant,${ }^{55}$ many argue or argue, ${ }^{56}$ restless, anxious, and reluctant

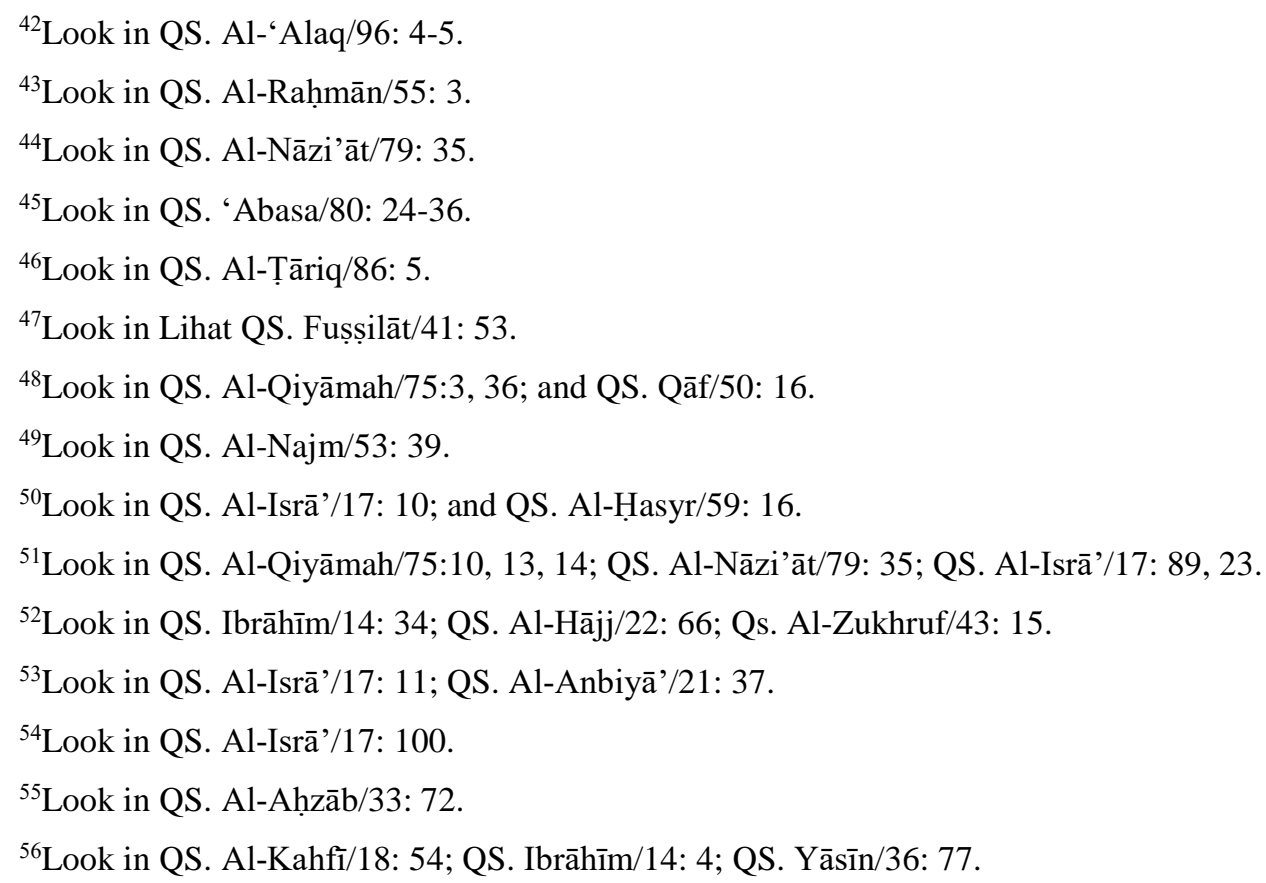


to help, ${ }^{57}$ destined to struggle and suffer, ${ }^{58}$ ungrateful, ${ }^{59}$ sinful, ${ }^{60}$ guilty apocalypse.${ }^{61}$ When connected with human traits in the first category, God becomes a paradoxical person, who struggles to overcome two conflicting conflicts: the power to follow fitrah (bearing God's trust) and strength follow a negative prediction. These two powers are described by the third category of verses. ${ }^{62}$

One interesting thing to see is that the process of creating humans or the origin of human events is attributed to the concepts of human and basyar at once. As human beings are created from clay, like land. ${ }^{63}$ Similarly, basyar comes from clay, which is a combination of soil ${ }^{64}$ and water. ${ }^{65}$ This is what prompts the writer to conclude that the process of human creation is symbolically illustrated. Characteristics of basyari and human characteristics. According to Qardhawi man is a combination of land power and divine gust. The first is the material element and the second is spiritual elements. The first is the basyari element, the second is the human element. Both must be combined in balance. It is not permissible to reduce the rights of the body to fulfill the rights of the soul, and it must not reduce the rights of the soul to fulfill the rights of the body. ${ }^{66}$

The word al-nass refers to humans as social beings. The word al-nass is the most mentioned in the Qur'an, which is as much as 240 times. ${ }^{67}$ The use of the word al-nass in the Qur'an includes: First, many verses that indicate social groups with their characteristics. The verses are commonly known as the phrase "wa min al-nās". if this expression is explored, it can be found various groups of people who claim to be believers, but actually do not believe, ${ }^{68}$ they tend to do idolatrous acts, ${ }^{69}$ and only

${ }^{57}$ Look in QS. Al-Ma'ārij/70: 19; QS. Ṭāhā'/20: 21.

${ }^{58}$ Look in QS. Al-Insyiqāq/84: 6; QS. Al-Balād/90: 4.

${ }^{59}$ Look in QS. Al-‘'Ādiyāt/100: 6.

${ }^{60}$ Look in QS. Al-‘Alaq/96: 6; QS. Al-Qiyāmah/75: 5.

${ }^{61}$ Look in QS. Maryam/19: 66.

${ }^{62}$ Rakhmat, Islam Dan Pluralisme Akhlak Quran Menyikapi Perbedaan., h. 127-130.

${ }^{63}$ Look in QS. Al-H\{ijr/15: 26; QS. Al-Raḥmān/55: 14; QS. Al-Mu'minūn/23: 12; QS. AlSajadah/32:7.

${ }^{64}$ Look in QS. Al-Hijr/15: 28; QS. Șād/38: 71; QS. Al-Rūm/30:20.

${ }^{65}$ Look in QS. Al-Furqān/25: 54.

${ }^{66}$ Rakhmat, Islam Dan Pluralisme Akhlak Quran Menyikapi Perbedaan., h. 131-132.

${ }^{67} \mathrm{Al}$-Ṭabrānī, Al-Mu'jam Al-Kabīr.

${ }^{68}$ Look in QS. Al-Baqarah/2: 8.

${ }^{69}$ Look in QS. Al-Baqarah/2: 165. 
think of worldly life, ${ }^{70}$ fascinated by talk of world life but hostile to truth ${ }^{71}$ always arguing with God without knowledge instructions, and al-kitab, ${ }^{72}$ worship with a weak faith, ${ }^{73}$ often put forward misleading arguments. ${ }^{74}$ Nevertheless, some of them are willing to sacrifice themselves to seek Allah's willingness. ${ }^{75}$

Second, by noticing the expression "aksar al-nās", it can be concluded that most humans have low quality, both in terms of science and in terms of faith. In the Qur'an, most people have negative characteristics, including; man is not knowledgeable,${ }^{76}$ not very grateful,${ }^{77}$ unbelieving, ${ }^{78}$ wicked,${ }^{79}$ neglecting the verses of Allah, ${ }^{80}$ infidels, ${ }^{81}$ and most humans must get the punishment. ${ }^{82}$ The verses of the Qur'an are emphasized by verses that show the least group of people who believe, ${ }^{83}$ knowledge ${ }^{84}$ thankful, ${ }^{85}$ survived the punishment of Allah, ${ }^{86}$ and are not deceived by Satan. ${ }^{87}$ These characteristics are summarized in QS. Al-An'am/6: 116 which states that "... if you follow most of the things on earth, they will lead you astray from the path of Allah."

The third, Al-Qur'an affirms that the Al-Qur'an's instructions are not only intended for humans individually but also socially. In the Al-Qur'an the word al-nas is

${ }^{70}$ Look in QS. Al-Baqarah/2: 200.

${ }^{71}$ Look in QS. Al-Baqarah/2: 204.

${ }^{72}$ Look in QS. Al-Hājj/22: 3, 8; and QS. Luqmān/31: 20.

${ }^{73}$ Look in QS. Al-Hājj/22: 11; and QS. Al-Ankabūt/29: 10.

${ }^{74}$ Look in QS. Lukmān/31: 6.

${ }^{75}$ Rakhmat, Islam Dan Pluralisme Akhlak Quran Menyikapi Perbedaan., h. 133-134.

${ }^{76}$ Look in QS. Al-‘A’rāf/7: 187; QS. Yusūf/12: 21; QS. Al-Qașaṣ/28: 68; QS. Al-Rūm/30: 6, 30; QS. Al-Jās̄iyā/45: 26; QS. Saba'/34: 28, 36; QS. Al-Mu'min/40: 57.

${ }^{77}$ Look in QS. Al-Mu'min/40: 61; QS. Al-Baqarah/2: 243; QS. Yūsuf/12: 38.

${ }^{78}$ Look in QS. Hūd/11: 17; QS. Yūsuf/12: 103; QS. Al-Ra'd/13: 1.

${ }^{79}$ Look in QS. Al-Mā'idah/5: 49.

${ }^{80}$ Look in QS. Yūnus/10: 92.

${ }^{81}$ Look in QS. Al-Isrā'/17: 89; QS. Al-Furqān/25: 50.

${ }^{82}$ Look in QS. Al-Hājj/22: 18.

${ }^{83}$ Look in QS. Șād/38: 24; QS. Al-Baqarah/2: 88; QS. Al-Nisā’/4: 46, 66, 155.

${ }^{84}$ Look in QS. Al-Kahfi/18: 22; QS. Al-A'rāf/7: 3; QS. Al-Naml/27: 62; QS. Al-Mu'min/40: 58; QS. Al-Hāqqah 69: 42.

${ }^{85}$ Look in QS. Saba'/34: 13; QS. Al-A'rāf/7: 10, 23, 78; QS. Al-Mulk/ 67: 23; QS. AlSajadah/32: 9.

${ }^{86}$ Look in QS. Hūd/11: 116.

${ }^{87}$ Look in QS. Al-Nisā'/4: 83. 
often associated with a clue or a book. ${ }^{88}$ From this point of view, it appears that the Qur'an tends to mention the word al-nas as a biological, psychological and social being. Humans as basyar are related to material elements that are symbolized by the earth element. In this situation, humans automatically submit to God's destiny in the universe, as well as obedience to the sun, animals, and plants. Humans in the sense of basyar by themselves musayyar. However, human is insan beings related to divine gusts. He was subject to rules, but he was given the power to submit or escape from him, humans became mukhayyar (supernatural) beings, humans absorbed the rabbanitraits as revealed by Ibn 'Arabi. The characteristics referred to as sama', basar, kalam, and qadar. Humans carry out the Divine region with all its consequences to be responsible for all its actions. ${ }^{89}$

If the Prophet Muhammad was considered as a normal human being in general, then it would not be wrong to be confronted with his position as a biological (basyar), but if the Prophet Muhammad was regarded as an insan or person who tended to have characteristics of wrong traits and attitudes, miserly-generous, not very grateful, and so on, so it is, of course, different when compared to humans in general. Therefore, assuming the Prophet Muhammad as a human being in general because he ate, drank, married, and so on was the logic used by the infidels to reject the preaching of the Prophet Muhammad. because of seeing the Prophet as the infidels saw themselves. This was revealed by Allah in the Qur' an by quoting the words of the infidels: "Isn't he as banned as you, he eats what you eat, and he drinks what you drink." Then the verse is confirmed in QS. Al-Furqan/25: 7: "did not the apostle eat food and walk in the market."

When evaluating the Messenger of Allah be like ordinary people by making benchmarks on the biological side, such as eating, drinking, marriage, and so on. This is a false judgment according to the context of the verses of the Qur'an which the author explained earlier. There are a number of parties who doubt that a human being can not imagine sinning. The expression can easily be refuted by proposing an analogy that even ordinary humans can be maintained from the actions of sin and error with an awareness of the right or wrong actions. Therefore, if all human beings know and realize from the bottom of their hearts that the slanderous actions that they commit will get the consequences of accountability and punishment on the day of court, then of course they consider, even avoiding these actions, human error, in general, is due to science what they have is only embedded in the heart, but it does not manifest in the conviction to be applied in my daily behavior. This is the reason why humans continue to do evil even though they have known it. ${ }^{91}$ Therefore, the main factor for humans to

27.

${ }^{88}$ Look in QS. Al-Hadīd/57: 25; QS. Al-Nisā'/4: 170; QS. Ibrāhīm/14: 35; QS. Al-Zumar/39:

\footnotetext{
${ }^{89}$ Rakhmat, Islam dan Pluralisme Akhlak Quran Menyikapi Perbedaan., h. 135-136.

${ }^{90}$ Look in QS. Al-Aḥzāb/33: 33.

${ }^{91}$ Qira'ati, Ushuluddin (Lesson from Al-Qur'an)., h. 258.
} 
be able to guard themselves against various sins and mistakes is to increase faith, comprehensive knowledge to be believed and applied in their daily behavior.

\section{The Infallibility Of The Prophet Muhammad As A Human}

According to Shihab in Sunnah-Syiah Bergandengan Tangan: Mungkinkah? Kajian atas Konsep Ajaran dan Pemikiran reveals the views of the Shi'a group who believe that the entire Prophet referred to in the Qur'an, including the Prophet Muhammad, was preserved from mistakes and sins. For the Shia group, the Prophet Muhammad was infallible in totality both as a child and as an adult. While the $A h l u$ Sunnah wa al-Jama'ah group (abbreviated as Sunni) understands that the Prophet Muhammad is infallible in conditional totality, for example, the Prophet Muhammad was infallible when receiving and delivering revelations. ${ }^{92}$ This difference is caused by the interpretation of the verses of the Qur'an which mention the infallibility of the Prophet Muhammad as the author mentioned before.

According to Taba'taba $\vec{i}$ that the Prophets were sent by Allah to broadcast religious teachings which were based on revelations and also accompanied by various miracle proofs to strengthen the legality of the da'wah they delivered. They convey religious teachings according to the level of ability of the people they face. The Prophets based their duties as messengers by basing on ontological values which included three elements, namely revelation, acceptance, and maintenance. Therefore, it is impossible for a Prophet to make mistakes in conveying the minutes of religious teachings that they teach because they are always accompanied by revelation so that they are kept awake from this negligence. The form of maintenance or accompaniment of Allah to the Prophets through revelation is, of course, contradictory to the behavior of the mistakes they make, so that these behaviors can conflict with the purpose of the da'wah they hold. ${ }^{93}$ Taba'taba'i based his opinion based on QS. Al-An'am / 6: 87:

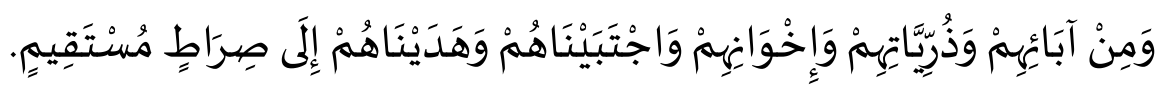

The translation:

And We increase (also) the degree of their fathers, descendants, and brethren. And We have chosen them - to be prophets and apostles - and We have appointed them to the right path.

According to Taba'taba $\overrightarrow{1}$ in his commentary that the verse above implies the statement of the Prophets who are chosen humans, and shows the legality of their infallibility. ${ }^{94}$ In addition, other information can be seen through QS. Al-Jin/72: 2628, as follows:

\footnotetext{
${ }^{92}$ Muhammad Quraish Shihab, Sunnah-Syiah Bergandengan Tangan: Mungkinkah? Kajian Atas Konsep Ajaran Dan Pemikiran, Cet. III. (Jakarta: Lentera Hati, 2007), 95.

${ }^{93}$ Muhammad Husain Taba]țaba'̄̄, Shi'ite Islam, ed. Sayyed Husein Nasr (New York: State University of New Yor Press, 1975), h. 131-134.

${ }^{94}$ Jalaluddin Rakhmat, Soal-Soal Islam Kontemporer, Cet. I. (Bandung: Mizan, 1998), h. 291.
} 


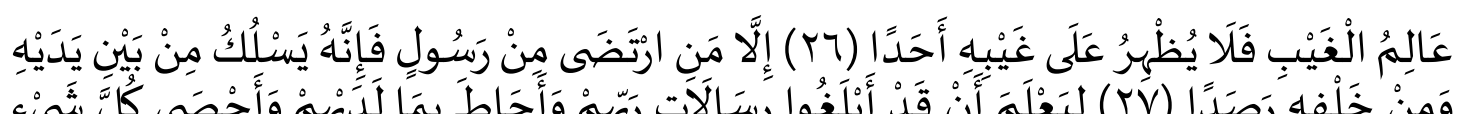

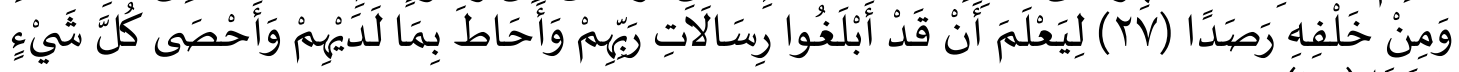

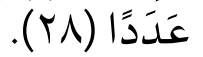

The translation:

(He is God) who knows the unseen, So He does not show anyone about the unseen. Except for the Apostle whom He is pleased with, Then He Held Guardians (angels) in the face and behind him.

According to Mutahhari in Man and Universe states that the above verse is a characteristic of the infallibility of the Prophets which includes their vigilance from all forms of error which impact sin. According to him, the Prophet was not overpowered by his personal desires, but they were subject to the revelations they received from God. Therefore the infallibility of the Prophet is an inherent matter, even though later the scholars still debated the maximal meaning operationally. Does the debate revolve around the problem of how God keeps the Prophets awake as ordinary human beings? Is it by the way angels come to prevent the Prophets when they make mistakes, like a father who prevents his child from getting lost?, or infallibility pinned to the Prophets have been inherent in themselves since the beginning, so that they do not have the opport unity to make the slightest mistake, like an angel who only does obedience and will not be able to commit immorality, or can he do it, because the Prophet has been granted special intuition, faith, and belief so that his level is different from humans normal. ${ }^{95}$

Basically, faith is a measure of the quality of one's spirituality so that if someone has a strong level of faith, it is difficult for him to be trapped in a puddle of mistakes. A person who has a good quality of faith, even a small mistake will be easy for him to realize and be able to avoid, a condition like this that the writer understands as part of the values of infallibility. Infertility is the result of internal human production itself based on the quality of established faith through various efforts of spirituality that it seeks. This means that infallibility is not the result of external intervention outside of the human self itself, because if infallibility is obtained through God's intervention alone, it is difficult to recognize the superiority of the infallibility, because it is present from the externalized results of transcendence, not from the results of human effort itself naturally. ${ }^{96}$

According to Mutahhari that infallibility pinned to the Prophets comes from intuition based on the quality of their faith ${ }^{97}$ Therefore, the infallibility possessed by the Prophets is not purely obtained through the efforts of spirituality based on the religious teachings they obtain from Allah through revelation. This was also expressed

\footnotetext{
${ }^{95}$ Murtadha Muthahhari, Man And Universe, ed. Ilyas Hasan, Digital. (CreateSpace Independent Publishing Platform, 2018), h. 118.

${ }^{96}$ Murtadha Muthahhari, Man And Universe, h. 118-119.

${ }^{97}$ Murtadha Muthahhari, Man and Universe, h. 119
} 
by Sameh Sa'id that of the various attitudes of the Prophets, especially Muhammad (PBUH), Messenger of Allah, who chose more silence than saying something that was not useful or did not contain elements of truth. ${ }^{98}$ This is also mentioned in the Qur'an QS. Al-Najm / 53: 3-4 as follows:

$$
\text { وَمَا يَنْطِقُ عَنِ الْهَوَى (r) إنْْ هُوَ إِلَّا وَحْيَ يُوحَى (ع) }
$$

The translation:

And nothing is said what the Qur'an recites according to the wishes of its desires. His words are nothing but revelations revealed to him).

Besides the verse above, other information can also be found through the history of the Hadith which states about the description of the behavior of the Messenger of Allah, which was recorded through a question posed by a friend to Ayesha (Wife of the Prophet), he replied that "the morality of the Prophet is AlQur'an." 99 Furthermore, al-Nasr expressed his opinion which was different from the above opinion, he acknowledged that the Holy Prophet as the bearer of the sacred treatise, a Prophet or Apostle at the same time played a role as an ordinary human being. The Prophet continued to do what humans did in general. Of course, that is meant if the problem is outside of the apostolic mission. ${ }^{100}$ The behavior of the human side is when the behavior of the Prophets is related to human needs, for example, the Prophets need food, both before and after bearing the title of the Prophet, as well as the right to have offspring, earn a living, avoid various kinds of dangers that can threaten her, and so on. ${ }^{101}$ Therefore it can be understood that basically, the Prophets were no different from humans in general in the basyar region. Because significant specialization between the Prophet and ordinary people is only because the Prophets received and delivered revelations according to God's instructions. Therefore God does not necessarily transform the physical and psychological manifestations of the Prophets from ordinary people and then become the manifestation of angels after obtaining the treatise. Rather, God still maintains the embodiment of the Prophets as ordinary human beings in general. ${ }^{102}$ The context can also be seen in the Qur'an QS. al-An'am / 6: 50:

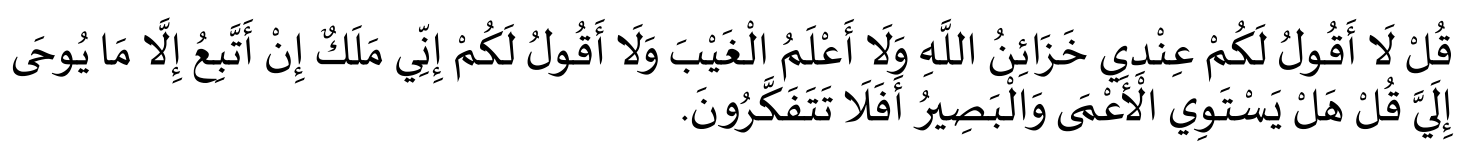

\footnotetext{
${ }^{98}$ Muhammad Sameh Sa'id, Muhammad Sang Yatim Janji dan Kemenangan yang Dinanti, Cet. I. (Bandung: Cordoba, n.d.), h. 461.

${ }^{99}$ Jalaluddin Rakhmat, Islam Aktual Refleksi Sosial Seorang Cendekiawan Muslim, Cet.XV. (Bandung: Mizan, 2004), h. 202.

100،Abdul Jalīl 'Isā Abū Al-Naṣr, Ijtihād Al-Rasūl Ṣallallāh 'Alayh wa Sallām (Cairo: Dār Ihyā' al-Kutub al-’Arabiyah, 1950), 30-31.

${ }^{101}$ Abdul Jalīl 'Isā Abū Al-Naṣr, Ijtihād Al-Rasūl Șallallāh 'Alayh wa Sallām, h. 33-34.

${ }^{102}$ Abdul Jalīl 'Isā Abū Al-Naṣr, Ijtihād Al-Rasūl Șallallāh 'Alayh wa Sallām, h. 34-35.
} 
The translation:

Say: I have not told you that the treasury of God is upon me, and I do not know that which is unseen, nor do I tell you that I am an angel. I did not follow except what was revealed to me. Say: "Is it the same with those who are blind with those who see?" Then do you not think about it?

The above verse is often used as a proposition to prove that the Messenger of Allah was an ordinary human being, but actually, this verse emphasizes that the Messenger of Allah is infallible and does not carry out ijtihad which is free from revelation control. The above verse also confirms that the Messenger of Allah was a basyar who did not follow anything except that which was revealed to him. Supported the explanation above, Wijaya in History of Prophethood in the Perspective of Nuzuli Interpretation expresses his opinion in accordance with the opinion of Al-Nasr. Wijaya said that there were several cases that showed the Prophet Muhammad's ijtihad when deciding related to a problem, the Prophet's ijtihad was then strengthened through revelation (Al-Qur' an) which came down as a confirmation of the results of the ijtihad. For example, the release of the Surah al-Anfal after the Battle of Badr related to the results of the Prophet's deliberations with his companions who decided to fight the Quraysh tribe. Likewise when the Prophet wanted to make a pilgrimage to the Ka'ba in the sixth year of the hijrah with some of his friends because he received orders through revelation or inspiration from Allah. After that, the Prophet was ordered to enter into an Hudaibiyah agreement with the Quraysh in order to make it easier for Muslims to make a pilgrimage to the Ka'ba. ${ }^{103}$

Another example also mentions that the Prophet Muhammad had received reprimand on several occasions, among them the Prophet Muhammad was rebuked when asking for a ransom of Badar prisoners of war when giving permission to hypocrites not to follow the Tabuk war. On another occasion also mentioned when the Prophet asked forgiveness for his brothers who died in infidels. Similarly, when the Prophet did not heed the arrival of a blind friend (Abdullah b. Ummi Maktum) on the sidelines of preaching before the leaders of the tribes in Mecca, this was marked by the decline of the surah 'Abasa. Other rebuke events also occur when the Prophet forbids something for himself that Allah forbids him, for example, to not connect with his wife at certain times. ${ }^{104}$

Responding to the problem of the spirit of reproof, Darwazah mentions in History of Prophethood that there is no relationship between the ijtihad, words, and behavior of the Prophet Muhammad who received a rebuke from Allah with his infallibility as the Prophet or Prophet. Ijtihad The prophet who gets the rebuke is not a sin that contradicts the values of infallibility as believed by Muslims. Infertility is 2016), h. 331.

${ }^{103}$ Aksin Wijaya, Sejarah Kenabian dalam Perspektif Tafsir Nuzuli, Cet. I. (Bandung: Mizan,

\footnotetext{
${ }^{104}$ Aksin Wijaya, Sejarah Kenabian dalam Perspektif Tafsir Nuzuli, h. 332.
} 
not something that makes the Prophet Muhammad forbidden to do, nor to make ijtihad related to various problems of people's lives, especially related to worldly problems. Therefore, basically, there is no contradiction between the events mentioned by the verses of the Qur'an above and the surah al-Najm which talks about the infallibility of the Prophet. It is precise if carefully considered that the Surah al-Najm is in line with the next verse when the Prophet saw the Angel in the Ufuq which was later strengthened by the Qur'an. ${ }^{105}$

Therefore according to the author, the phrase that there is no relation between ijtihad and the infallibility of the Prophet is a false expression. Because the opinion legalizes the Prophet's ijtihad, but it must also be believed that ijtihad is always under the guidance of revelation. Ijtihad carried out by the Prophet Muhammad must be understood as a form of humanity inherent in the Prophet Muhammad, but the position of ijtihad is not directly aligned with the value of truth or error, because revelation always guides the Prophet Muhammad in every ijtihad, but the guidance can come in a form of reprimand to correct the mistake caused by his ijtihad as a human being. This is what distinguishes between the humanity of the Prophet and humans in general. That the Prophet Muhammad could make a mistake as a human being, but that mistake was not allowed by Allah but would get a rebuke as a form of infallibility of the Prophet, according to the ulama in general, but some scholars understood it differently than the infallibility of the prophet was a part of him and deliver revelation.

\section{E. Conclusion}

Based on the description in the previous study, it can be concluded that the Prophet Muhammad remained as a perfect human being with the quality of his totality. The phenomenon of error in establishing ijtihad, which is claimed by some scholars as a form of inadequacy, is an interpretation done prematurely and not through a comprehensive analyst process. It should be emphasized that ijtihad carried out by the Prophet Muhammad is a spiritual aspect of ikhtiyarī. This means that every ijtihad carried out by the Prophet Muhammad is always through strict supervision from Allah. That is why when the Prophet Muhammad erred in establishing ijtihad, at the same time, a revelation came to reprimand and correct the error. The context is what the authors consider to be a form of infallibility because humans do not possess it in general. The claim is based on an analysis of the use of popular terms in QS alKahfi/18: 110. The fame in verse shows his status as a human who always does something based on $y \bar{u} h \bar{a}$ (revelation guidance). That is why the discussion related to Nabu Muhammad's infallibility in the context of the use of the great bounty cannot be separated from his position as a human being as well as the Prophet who received revelation. This argument is reinforced through the interpretation of the QS. Al-Najm: $3-4$, which mentions that all activities of the Prophet Muhammad saw sparked from the impulse. It is in this context that distinguishes the term basyar when pinned on humans in general with the basic terms embedded in the Prophet Muhammad.

${ }^{105}$ Aksin Wijaya, Sejarah Kenabian Dalam Perspektif Tafsir Nuzuli, h. 332-333. 


\section{BIBLIOGRAPHY}

Ahmed, Rumee. "The Ethics of Prophetic Disobedience: Qur'an 8: 67 at The Crossroads of Islamic Sciences.” Journal of Religious Ethics Vol. 39, no. 3 (2011): 440-457.

Al-Dārimí, Abū Muhammad 'Abdullah b. 'Abdurrahmān b. al-Fadal b. Bahrān b. 'Abdul Șa’ad. Musnad Al-Dārimī. Cet. I. Arab Saudi: Dār al-Mughní, 2000.

Al-Naisabūīi, Muslim b. al-Hajaj Abū al-Hasan al-Qusyairí. Sahịh Muslim. Edited by Muhammad Fu'àd 'Abdul Bāqi. Beirut: Dār Ihyà Turàs Al-' Arabí, n.d.

Al-Nașr, 'Abdul Jalī 'Isā Abū. Ijtihād Al-Rasūl Sallallăh 'Alayh wa Sallām. Cairo: Där Ihyà Al-Kutub Al-'Arabiyah, 1950.

Al-Naysaburī, Muslim b. Al-Hajjaj Abū Al-Hasan al-Qusyayrĩ. Al-Musnad al-Sahịh al-Mukhtasar bi al-Naqli al-'Adl 'an Rasülillăh saw. Beirut: Dār Ihyā al-Turas al'Arabí, n.d.

Al-Sijistānī, Abū Daud Sulaiman b. al-Asy'ats. Sunan Abī Daud. Cet. I. Beirut: Dār al-Kutub Risalah al-'Ilmiyah, 2009.

Al-Ṭabarī, Mụhammad b. Jarīr. Jāmī‘ Al-Bayān fí Ta’wìl Ayi Al-Qur'ān. Cet. I. Beirut: Mu'assasah al-Risalāh, 2000.

Al-Ṭabrānī, Sulaiman b. Ahmad b. Ayyub Abu al-Qāsim. Al-Mu'jam al-Kabīr. Cairo: Maktabah Ibnu Taimiyyah, 1415.

Ferrero, Mario. "The Infallibility of the Pope." Economics of Governance Vol. 12, no. 1 (2011): 89-99.

Fuadi, Alfin Rahmat. "Pandangan Mufasir Tentang Sifat Kemaksuman Nabi Muhammad Saw.” Aceh: Universitas Islam Negeri Ar-Raniry, 2018.

Harahap, Syahrin, and Hasan Bakti Nasution. ,Ensiklopedia Akidah Islam. Jakarta: Kencana, 2009.

Makhluf, Syaikh Hasanain Muhammad. Al-Mu'jam al-Mufahras li Kalimät Al-Qur'ān al-Karim, Tafsìr wa Bayān Kalimät Al-Qur'ān al-Karim. Cet. I. Beirut: Där Ibn Kasīir, 2005.

Manẓur, Ibnu. Lisān al- 'Arab. Beirut: Dār Șādir, 1410.

Munawwir, Ahmad Warson. Kamus Al-Munawwir. Surabaya: Pustaka Progressif, 1997.

Muthahhari, Murtadha. Man And Universe. Edited by Ilyas Hasan. Digital. CreateSpace Independent Publishing Platform, 2018.

Qira'ati, Muhsin. Ushuluddin (Lesson from Al-Qur'an). Edited by M.J Bafaqih and Dede Azwar Nurmansyah. Jakarta: Cahaya, 2007. 
Rakhmat, Jalaluddin. Islam Aktual Refleksi Sosial Seorang Cendekiawan Muslim. Cet.XV. Bandung: Mizan, 2004.

Islam Dan Pluralisme Akhlak Quran Menyikapi Perbedaan. Cet. II. Jakarta: Serambi Ilmu Semesta, 2006.

- Soal-Soal Islam Kontemporer. Cet. I. Bandung: Mizan, 1998.

Rizvi, Sayyid Muhammad. The Infallibility of the Prophets in the Qu'ran. Cambridge: Create Space Independent Publishing Platform, 2014.

Sa'id, Muhammad Sameh. Muhammad Sang Yatim Janji Dan Kemenangan Yang Dinanti. Cet. I. Bandung: Cordoba, n.d.

Shihab, Muhammad Quraish. Sunnah-Syiah Bergandengan Tangan: Mungkinkah? Kajian Atas Konsep Ajaran Dan Pemikiran. Cet. III. Jakarta: Lentera Hati, 2007.

_. Wawasan Al-Qur'an: Tafsir Maudhu'i Atas Perbagai Persoalan Umat. Cet. XIII. Bandung: Mizan, 2003.

Sriwahyuni, Sriwahyuni. "Kemaksuman Nabi: Kajian Terhadap Ayat-Ayat 'Itāb Terhadap Nabi Muhammad Saw." Jurnal At-Tibyan: Jurnal Ilmu Alquran dan Tafsir 2, no. 2 (2017): 189-206.

Subhānī, Syeikh Ja'far. Mafăhim Al-Qur'ān. Beirut: Mu'assasah Al-Tarikh al-'Arabī, 2010.

Țabataba'i, Muhammad Husain. Shi'ite Islam. Edited by Sayyed Husein Nasr. New York: State University of New Yor Press, 1975.

Tajuddin, Muhammad. "Kontroversi Kemaksuman Rasul Ulul Azmi Dalam Al-Qur'an (Studi Komparatif Tafsir Al-Thabarsi Dan Al-Qurthubi).” Malang: Universitas Islam Negeri Maulana Malik Ibrahim, 2018.

Wijaya, Ahsin. Kamus Ilmu Al-Qur'an. Jakarta: Amzah, 2012.

Wijaya, Aksin. Sejarah Kenabian Dalam Perspektif Tafsir Nuzuli. Cet. I. Bandung: Mizan, 2016. 


\section{Guidelines}

\section{Submission of Article}

urnal Adabiyah welcomes the articles submission with the main themes on Humanities and Islamic Studies with the emphasis on interdisciplinary and intertextuality approach. Adabiyah is thematicly published twice in a year. ie the theme of the humanities in June and the Islamic Study in December.

Themes related to Islamic Studies are textual studies, scriptural traditions, Islamic law, and theology; and those related to Humanities are language, literature, history, and culture. This scholarly journal Guarantees that the editor decision based on the peer review results will not exceed 30 days from the paper submission date.

Authors are invited to read our archives; to find the relevant topics for the journal, and to submit complete unpublished scientific researches, which are not under review in any other conferences or academic journal.

\section{PUBLICATION ETHIC}

Publication Ethic and Malpractice Statement

Jurnal Adabiyah is a peer-reviewed journal, published twice a year by the Faculty of Adab and Humaniora, Alauddin State Islamic University of Makassar Indonesia. It is available online as open access sources as well as in print. This statement clarifies ethical behaviour of all parties involved in the act of publishing an article in this journal, including the author, the editor-in-chief, the Editorial Board, the reviewers, and the publisher. This statement is based on COPE's Best Practice Guidelines for Journal Editors.

Ethical Guideline for Journal Publication

The publication of an article in Jurnal Adabiyah, is an essential building block in the development of a coherent and respected network of knowledge. It is a direct reflection of the quality of the work of the authors and the institutions that support them. Peer-reviewed articles support and embody the scientific methods. It is therefore important to agree upon standards of expected ethical behavior for all parties involved in the act of publishing: the author, the editor, the reviewer, the publisher, and the society. As the publisher of Jurnal Adabiyah, the Faculty of Adab and Humaniora takes its duties of guardianship over all stages of publishing seriously and it recognizes its ethical and other responsibilities. The Faculty of Adab and Humaniora committed to ensuring that advertising, reprint or other commercial revenue has no impact or influence on editorial decisions.

\section{Publication Decisions}

The editors of Jurnal Adabiyah is responsible for deciding which articles submitted to the journal should be published. The validation of the work in question and its importance to researchers and readers must always drive such decisions. The editors may be guided by the policies of the journal's editorial board and constrained by such legal requirements as shall then be in force regarding libel, copyright infringement, and plagiarism. The editors may confer with other editors or reviewers in making their decisions.

\section{Plagiarism Screening}

It is basically author's duty to only submit a manuscript that is free from plagiarism and academically malpractices. The editor, however, will check all submitted papers through Turnitin.

\section{Fair Play}

An editor at any time evaluates manuscripts for their intellectual content without regard to race, gender, sexual orientation, religious belief, ethnic origin, citizenship, or political philosophy of the authors. 


\section{Confidentiality}

The editors and any editorial staff must not disclose any information about a submitted manuscript to anyone other than the corresponding author, reviewers, potential reviewers, other editorial advisers, and the publisher, as appropriate.

\section{Disclosure and Conflicts of Interest}

Unpublished materials disclosed in a submitted manuscript must not be used in editors' own research without the express written consent of the author.

\section{DUTIES OF AUTHORS}

\section{Reporting Standards}

Authors of reports of original research should present an accurate account of the work performed as well as an objective discussion of its significance. Underlying data should be represented accurately in the paper. A paper should contain sufficient detail and references to permit others to replicate the work. Fraudulent or knowingly inaccurate statements constitute unethical behaviour and are unacceptable.

\section{Originality and Plagiarism}

The authors should ensure that they have written entirely original works, and if the authors have used the work and/or words of others that this has been appropriately cited or quoted.

\section{Multiple, Redundant, or Concurrent Publication}

An author should not in general publish manuscripts describing essentially the same research in more than one journal or primary publication. Submitting the same manuscript to more than one journal concurrently constitutes unethical publishing behaviour and is unacceptable.

\section{Acknowledgement of Sources}

Proper acknowledgment of the work of others must always be given. Authors should cite publications that have been influential in determining the nature of the reported work.

\section{Authorship of the Paper}

Authorship should be limited to those who have made a significant contribution to the conception, design, execution, or interpretation of the reported research. All those who have made significant contributions should be listed as co-authors. Where there are others who have participated in certain substantive aspects of the research project, they should be acknowledged or listed as contributors. The corresponding author should ensure that all appropriate co-authors and no inappropriate co-authors are included on the paper, and that all co-authors have seen and approved the final version of the paper and have agreed to its submission for publication.

\section{Disclosure and Conflicts of Interest}

All authors should disclose in their manuscript any financial or other substantive conflict of interest that might be construed to influence the results or interpretation of their manuscript. All sources of financial support for the project should be disclosed.

\section{Fundamental errors in Published Works}

When an author discovers a significant error or inaccuracy in his/her own published work, it is the author's obligation to promptly notify the journal editor or publisher and cooperate with the editor to retract or correct the paper.

\section{PLAGIARISMI}

It is basically author's duty to only submit a manuscript that is free from plagiarism and academically malpractices. The editor, however, will check all submitted papers through Turnitin. 


\section{AUTHOR GUIDELINES}

\section{Guidelines for online submission:}

1. Author should first register as Author to the website of Jurnal Adabiyah. Click the menu "register" to register as an author.

2. Once after the author is registered, please login to the website of Jurnal Adabiyah and submit the article through online submission (with the stat us of active submissions).

3. The article should follow the standard template of Jurnal Adabiyah provided in the website.

4. The citation and bibliography should follow the Turabian citation style.

5. Author is restricted not to send his/her article to another journal before having confirmation from the editorial team (approximately 4 weeks right after the article submitted).

6. Author should follow editorial decisions and recommendations related to the article completion. All reviews and assessements will be informed through online submission.

Article submitted to Jurnal Adabiyah editorial board must follow these guidelines:

1. Article should be based on the scientific research in the field humanities and Islamic studies;

2. Article must be an original work and has not been previously published;

3. Article should be written in Arabic or English languages;

4. Article must be typed in one-half spaced on A4-paper size;

5. Article's length is about $6,000-10,000$ words;

6. All submission must include a 150-250 word abstract;

7. Abstract should be written in 3 languages; Arabic, English, and Bahasa;

8. Full name(s) of the author(s) must be stated, along with his/her/their institution and complete address;

9. All submission should be in OpenOffice, Microsoft Word, RTF, or WordPerfect document file format;

10. Bibliographical reference must be noted in footnote and bibliography according to Jurnal Adabiyah style. In addition, it is suggested for author(s) to use reference manager tools such as 30 MENDELEY or 2 otero

When a source is cited for the first time, full information is provided: full name(s) of author(s), title of the source in italic, place of publication, publishing company, date of publication, and the precise page that is cited. For the following citations of the same source, list the author's last name, two or three words of the title, and the specific page number(s). The word ibid., op.cit., and loc.cit. are may not be used any more.

\section{Example in footnotes:}

${ }^{1}$ Mircea Eliade (ed.), The Encyclopedia of Religion, vol. 8 (New York: Simon and Schuster, 1995), h. 18.

${ }^{2}$ Norman Daniel, Islam and the West (Oxford: One World Publications, 1991), h. 190.

${ }^{3}$ Syeikh Ja'far Subhānī, Mafăhim Al-Qur'ān (Beirut: Mu'assasah Al-Tarikh Al-'Arabī, 2010)., Juz 5, h. 231. 
${ }^{4}$ Syeikh Ja'far Subhānī, Mafăhim Al-Qur'ān, h. 8-9.

\section{Example in bibliography:}

Subhānī, Syeikh Ja'far. Mafāhim Al-Qur'ān. Beirut: Mu'assasah Al-Tarikh Al-'Arabī, 2010.

Eliade, Mircea (ed.). The Encyclopedia of Religion, vol. 8. New York: Simon and Schuster, 1995.

Daniel, Norman. Islam and the West. Oxford: One World Publications, 1991.

Shihab, Muhammad Quraish. Sunnah-Syiah Bergandengan Tangan: Mungkinkah? Kajian Atas Konsep Ajaran Dan Pemikiran. Cet. III. Jakarta: Lentera Hati, 2007.

Detail informations of the footnotes:

1. Holy book

Al-Qur'ân, Al-Baqarah/2: 185.

Perjanjian Baru, Mrk. 2: 18.

2. Qur'anic translation

${ }^{1}$ Departemen Agama RI, al-Qur'an dan Terjemahannya (Jakarta: Darus Sunnah, 2005), h. 55.

3. Book

${ }^{1}$ Muḥammad 'Ajjaj al-Khațib, Ușl al-Hadith: 'Ulumuh wa Mușțalaḥuh (Beirut: Dâr al-Fikr, 1989), h. 57.

4. Translation Books

${ }^{1}$ Toshihiko Izutsu, Relasi Tuhan dan Manusia: Pendekatan Semantik terhadap al-Qur'an, terj. Agus Fahri Husein dkk (Yogyakarta: Tiara Wacana, 2003), h. 14.

5. Voluminous book

${ }^{1}$ Muḥammad al-Ṭâhir b. 'Ashur, al-Tạnn̄̄r wa al-Tanwīr, Vol. 25 (Tunisia: Dâr al-Suhûn, 2009), h. 76.

${ }^{1}$ Muḥammad b. Ismā‘īl al-Bukharī, al-Jami` al-Ṣahịḥ, Vol. 2 (Beirut: Dar al-Kutub al-‘Ilmìyah, 1999), h. 77.

6. Article in book

${ }^{1}$ Sahiron Syamsuddin, "Metode Intratekstualitas Muhammad Shahrur dalam Penafsiran al-Qur'an" dalam Abdul Mustaqim dan Sahiron Syamsuddin (eds.), Studi al-Qur'an Kontemporer: Wacana Baru Berbagai Metodologi Tafsir (Yogyakarta: Tiara Wacana, 2002), h. 139.

7. Article in encyclopaedia

${ }^{1}$ M. Th. Houtsma, "Kufr” dalam A. J. Wensinck, at al. (ed.), First Encyclopaedia of Islam, Vol. 6 (Leiden: E.J. Brill, 1987), h. 244.

8. Article in journal

${ }^{1}$ Muhammad Adlin Sila, "The Festivity of Maulid Nabi in Cikoang, South Sulawesi: Between Remembering and Exaggerating the Spirit of Prophet", Studia Islamika 8, no. 3 (2001): h. 9.

9. Article in mass media

${ }^{1}$ Masdar F. Mas'udi, "Hubungan Agama dan Negara", Kompas, 7 Agustus 2002. 
10. Article in Internet

${ }^{1}$ Muhammad Shahrūr, "Reading the Religious Teks: a New Approach" dalam http://www.shahrour.org/25 Februari 2010/diakses 5 Juni 2010.

11. Thesis or dissertation

${ }^{1}$ Syahruddin Usman, "KinerjaGuru Penddikan Agama Islam pada SMAN dan SMKN Kota Makassar”, Disertasi (Makassar: PPs UIN Alauddin, 2010), h. 200.

\section{COPYRIGHT NOTICE}

Authors who publish with this journal agree to the following terms:

1) Authors retain copyright and grant the journal right of first publication with the work simultaneously licensed under a Creative Commons Attribution License that allows others to share the work with an acknowledgement of the work's authorship and initial publication in this journal.

2) Authors are able to enter into separate, additional contractual arrangements for the non-exclusive distribution of the journal's published version of the work (e.g., post it to an institutional repository or publish it in a book), with an acknowledgement of its initial publication in this journal.

3)Authors are permitted and encouraged to post their work online (e.g., in institutional repositories or on their website) prior to and during the submission process, as it can lead to productive exchanges, as well as earlier and greater citation of published work (See The Effect of Open Access). 